\title{
Stenocarpella macrospora AND Stenocarpella maydis IN THE CERRADO AND SOUTHERN BRAZIL REGIONS
}

\section{Stenocarpella macrospora E Stenocarpella maydis NAS REGIÕES DO CERRADO E SUL DO BRASIL}

\author{
Justino Luiz MÁRIO ${ }^{1}$; Cassio Freitas GOZUEN ${ }^{2}$; Fernando Cezar JULIATTI ${ }^{3}$ \\ 1. Laboratório de Micologia e Proteção de Plantas - LAMIP, Instituto de Ciências Agrárias - ICIAG, Universidade Federal de \\ Uberlândia - UFU, Uberlândia, MG, Brasil; 2. Engenheiro Agrônomo; 3. Professor, Doutor, LAMIP-ICIAG-UFU, Uberlândia, MG, \\ Brasil. juliatti@ufu.br; justo.mario16@gmail.com
}

\begin{abstract}
Stenocarpella macrospora and Stenocarpella maydis may result in the seedlings death or cause rotting at the corn stalk base and in all or part of the ear. In addition, S. macrospora can cause leaf spot. Double-haploid strains from corn hybrids resistant to $S$. macrospora and S. maydis were identified. Also the incidence of these pathogens in the Cerrado and in Southern Brazil localities was determined. One hundred and forty double-haploid maize hybrids, in addition to the controls, were inoculated with S. macrospora and S. maydis and evaluated for resistance reaction in three locations of the Cerrado and three locations of the South regions. The grains attacked by these fungi were collected and variable quantities of $S$. macrospora, S. maydis and other fungal species were registered. The results demonstrated the prevalence of S. macrospora in the Cerrado as well as other non-Stenocarpella sp. fungi in the South. The city of Abelardo Luz (Santa Catarina) was the only place where S. maydis was found to have a higher incidence than $S$. macrospora. Environmental effects influence the prevalence of fungi, causing grain rot. These results indicated genetic gains in the selection of hybrids resistant to this fungi for use as direct breeders in Stenocarpella-corn pathological system research.
\end{abstract}

KEYWORDS: Diplodia sp. Rotten grain. Double-haploids.

\section{INTRODUCTION}

Corn (Zea maiz L.) is second in economic importance and cultivated area in the world. Stenocarpella maydis (Berk.) Sacc., Stenocarpella macrospora Earle, Fusarium verticillioides Sheld and Fusarium graminearum (Schw) are the principal agents of disease in terms of rot in the stalk and ear. These fungi reduce crop yield and depreciate product quality due to the production of toxins (EDDINS, 1930; PROZESKY et al., 1994; DORRANCE et al, 1998;. ROSSOUW et al, 2002a; HOUSE, et al, 2006;. GUTIERREZ, 2008 ).

In the natural environment, S. macrospora and $S$. maydis occur only in imperfect or asexual form (HOUSE et al., 2006). On summer the climatic conditions of Southern Brazil with warm days (25$\left.27^{\circ} \mathrm{C}\right)$ and mild nights $\left(12-15^{\circ} \mathrm{C}\right)$ are favorable $S$. maydis development (PEREIRA, 1995). In certain environments where the relative humidity is less than $50 \%$ S. macrospora produces more mycelium and pycnidia, growing faster than $S$. maydis and can infect plants at any phenological stage (DEL RIO, 1990).

In the ear symptoms usually begin shortly after fertilization. When infection occurs two weeks after pollination, the ear can become completely affected with a brownish-gray to off-white color in the fungus. Infected grains have a dull gray to black color and brown pycnidia can form on the tassel, floral bracts, ears and grains (HOUSE et al, 2006;. WOLOSSHUK; WISE, 2008).

Differentiation between these species can require breeding programs to use specific germplasm for each pathogen, according the program scope. However, there were few studies that focus on tropical germplasm and fewer that aim to identify resistance of these two pathogens (MARIO; REIS; JULIATTI, 2011). Thus, the present study aimed to identify resistance to $S$. macrospora and $S$. maydis of double=haploid corn hybrids and also verify the incidence of these pathogens in the Cerrado and in Southern Brazil regions. Results would provide valuable information to breeding programs on studies of the Stenocarpella-corn pathosystem.

\section{MATERIAL AND METHODS}

\section{Hybrids, environments and experimental design}

The hybrids examined resulted from a cross between two contrasting inbred lines conducted to determine their reaction to rot ear by Stenocarpella spp., MLR1 (resistant) and MLS1 (susceptible), both produced by from Monsanto.

One hundred and forty double-haploid lines were generated using a haploid frequency inductor in combination with colchicine treatment. These lines were crossed with a susceptible line tester (MLS4) and were unrelated to parental hybrids in 
order to generate an equal number of test intersections.

For chromosomal replication, seeds were immersed in a $.06 \%$ colchicine solution and $.5 \%$ dimethylsulfoxide (DMSO) for $12 \mathrm{~h}$ in the dark (DEIMLING, 1997) at room temperature. After duplication, the seedlings were washed for $20 \mathrm{~min}$ in running water and taken to the greenhouse.

The resulting hybrids were evaluated during the 2006/07 season in the Cerrado and Southern Brazil regions, in a totalizing six locations. In the Cerrado, evaluations were conducted in Irai de Minas, Uberlândia and Araguari, in the State of Minas Gerais. In the South, the trials were conducted in Pinhão and Guarapuava, in Paraná, and at Abelardo Luz, in Santa Catarina. Selection of these environments was mainly based on the historical incidence of grain rot obtained from each of the tested environment research programs. The adoption of direct sowing on straw for consecutive cycles was examined as a common practice as well as representative yield levels of the sampled regions.

The experimental design included randomized blocks with two replications per location. The experimental unit consisted of two rows of five $\mathrm{m}$, spaced $70 \mathrm{~cm}$ between each row. The plant density was 70,000 and 75,000 plants ha ${ }^{-1}$ in the Cerrado region and in the South, respectively. Mechanical sowing and harvesting were adopted. Plants were fertilized with 185-80-100 $\mathrm{kg} \mathrm{ha}^{-1}$ (N-P$\mathrm{K})$ in two doses. The first dose was applied at sowing, using 50-80-100 kg ha ${ }^{-1}$ (N-P-K). The second dose, of $135 \mathrm{~kg} \mathrm{ha}^{-1}$ of nitrogen, was applied 30 days after sowing. For weed control three liters per hectare of a mixture of atrazine $\left(200 \mathrm{~g} \mathrm{~L}^{-1}\right)$ and metalachlor $\left(200 \mathrm{~g} \mathrm{~L}^{-1}\right)$ were applied.

\section{Origin of the isolates and insulation}

The isolates used for the artificial inoculation were collected from infected ears in the region of Uberlândia. Isolation of the $S$. maydis and $S$. macrospora was conducted in the Plant Pathology Laboratory (Monsanto Company, Uberlândia, MG).

Grains with typical symptoms of the disease were placed in a humid chamber for seven days at $25^{\circ} \mathrm{C}$ and $95 \%$ relative humidity to stimulate pycnidia formation. Using a stereoscopic microscope and histological needle, pycnidia were collected from the grain, placed on a drop of water and covered with a slide. The conidia were examined for species identification and transferred to a Petri dish containing potato-dextrose-agar culture medium (PDA). The fungal species were
MÁRIO, J. L.; GOZUEN, C. F.; JULIATTI, F. C.

incubated for three days at $23-27^{\circ} \mathrm{C}$. Subsequently, the resulting colonies were transferred to new Petri dishes containing PDA and incubated for 3-4 days at $25^{\circ} \mathrm{C}$.

\section{Inoculation}

One hundred grams of grain sorghum were washed in plain water using a one L Erlenmeyer flask. The washed grains were placed in $125 \mathrm{~mL}$ of distilled water for $12 \mathrm{~h}$; the unabsorbed water was discarded. The substrate was then autoclaved twice at $125^{\circ} \mathrm{C}$ for $20 \mathrm{~min}$. Five discs of Stenocarpella spp. with $5,0 \mathrm{~mm}$ diameter were transferred to the sorghum substrate. The flasks were then incubated at $25^{\circ} \mathrm{C}$ until spore masses formed around the sorghum grains. They were then kept in a shaker for five days for equal distribution.

The inoculum was suspended in $250 \mathrm{~mL}$ of distilled water, agitated for $30 \mathrm{~min}$ and transferred to another flask through a funnel containing 5,0 layers of cheesecloth for filtration. The conidia were counted in a Newbauer chamber and the suspension was adjusted to a concentration of $4 \times 10^{4}$ conidia $\mathrm{mL}^{-1}$ (MARIO; REIS; JULIATTI, 2011).

Inoculation was performed throughout the experimental plot using the inoculum method which consisted of sprinkling a suspension of spores of $S$. macrospora and $S$. maydis over the floral bracts on the ear peduncles with the aid of an automatic dosing syringe. Each ear received $5,0 \mathrm{~mL}$ of suspension containing $4 \times 10^{4}$ conidia $\mathrm{mL}^{-1}$ of each specie. The inoculation was performed 10 to 15 days after the plants had reached $100 \%$ of female flowering (MARIO, 1998;. SMITH et al, 2005).

\section{Sample collection and data analysis}

The harvest was carried out when the grain reached $18-24 \%$ of moisture. Each plot produced a grain sample of approximately $300 \mathrm{~g}$ to estimate the percentage of rotted grain and identify the pathogens by the filter paper method using one hundred grains per repetition. The hybrid grain yields $\left(\mathrm{kg} \mathrm{ha}^{-1}\right)$ were also calculated.

Five resistant, 5 moderately resistant and 5 susceptible hybrids from each region of the study were evaluated for $S$. macrospora and/or $S$. maydis incidence. The control genotypes, CheckR and CheckS, were also evaluated. Any fungi collected from rotted grain, that were not Stenocarpella spp. were classified as "other fungi", beyond the focus of the present study. Hybrids were evaluated in three locations of the Cerrado (Savana conditions) and in three locations from southern Brazil. Two joint analyses were conducted, one in the three locations of the Cerrado region and another in three locations 
of the South, thus, six repetitions were analyzed by location.

The detection of $S$. macrospora and $S$. maydis in the grain was performed based on the color differences of the colonies, using filter paper method (MARIO; REIS, 2001) and growing at the growth chamber set at $25 \square 2^{\circ} \mathrm{C}$ and $12 \mathrm{~h}$ photoperiod.

\section{Analysis of Variance}

After the incubation period (chamber set at $25 \square 2^{\circ} \mathrm{C}$ ) the percentage of rotted grains per observation in two replications and randomized blocks was evaluated. After this was determined the percentage of grains with the both Stenocarpella species. The distribution and characterization of the incidence of rotted grain in the hybrids studied were evaluated by descriptive statistics and histograms. To estimate averages of the rotted grain incidence and their genetic components, we adopted the analysis model (SAS Institute Inc, vs 9.2), with completely randomized blocks:

$$
y_{i j}=\mu+b_{j}+t_{i}+e_{i j}
$$

Where: $y_{i j}$ is the value observed in the $j$ repetition from the test-cross $I ; \square \square$ is a constant inherent in all observations; $b_{j}$ is the random effect of the $j$ location; $b_{j} \sim \mathrm{N}\left(0, \square_{\mathrm{b}}^{2}\right), t_{i}$ is the test-cross $i t_{i}$ $\sim \mathrm{N}\left(0, \square{ }_{\mathrm{g}}^{2}\right)$ effect and $e_{i j}$ is the random error associated with $y_{i j}, e_{i j} \sim \mathrm{N}\left(0, \square^{2}\right)$ observation.

Components of genetic, residual and phenotypical variances were estimated by the moments method, by the solution of equations obtained comparing the mathematical expectations of the means squared means of the analysis of variance, to their observed values, determined by:

Genetic variance component:

$$
\hat{\sigma}_{g}^{2}=\frac{\text { GenotypeMS }- \text { ResidueMS }}{r} ;
$$

Residual variance component: $\hat{\sigma}^{2}=\operatorname{Re}$ sidueMS;

Phenotypic variance component: $\hat{\sigma}_{f}^{2}=\hat{\sigma}_{g}^{2}+\frac{\hat{\sigma}^{2}}{r}$;

Heritability: $\hat{h}^{2}=\frac{\hat{\sigma}_{g}^{2}}{\hat{\sigma}_{f}^{2}}$.

\section{RESULTS AND DISCUSSION}

Joint analysis of the 140 double-haploid hybrids tested in the two regions of Brazil showed significant statistical differences for the test crossing (hybrid) effect (Table 1). This indicated the existence of significant positive variance between hybrids derived from MLR1 / MLS1 crossing in the Cerrado region and in Southern Brazil ( Table 1).

Table 1. Joint analysis of variance for incidences of rotted grain in double-haploid corn hybrids tested in Cerrado and Southern Brazil regions.

\begin{tabular}{llllll}
\hline $\begin{array}{l}\text { Evaluated } \\
\text { Regions }\end{array}$ & $\begin{array}{l}\text { Residual } \\
\text { Variance }\end{array}$ & $\begin{array}{l}\text { Genetic } \\
\text { Variance }\end{array}$ & $\begin{array}{l}\text { G x L } \\
\text { Variance }\end{array}$ & $\begin{array}{l}\text { Phenotypic } \\
\text { Variance }\end{array}$ & Heritability \\
\hline Cerrado & 9.40 & 1.21 & .81 & 3.05 & .46 \\
$\begin{array}{l}\text { Southern } \\
\text { Brazil }\end{array}$ & 7.26 & 0.96 & .62 & 2.37 & .43 \\
\hline genotype x location & & & & &
\end{tabular}

*G x L: genotype $\mathrm{x}$ location

The joint analysis results for each region (Table 2) allowed classification of the hybrids according to the incidence of rotted grain. Overall, there was variation in the resistance of the hybrids by region showing an environmental effect on the expression of the trait.

The joint analysis of the Cerrado (Table 2) produced higher percentages of rotted grain incidence (MH55, MH48, MH89, MH77 and
MH128) ranging from 9.52 to $13.16 \%$. This was a higher incidence than found in the hybrid used as a rotted grain susceptibility control (CheckS) (7.34\%). The most resistant hybrids for the Cerrado were: MH2, MH9, MH134, MH106 and MH41, with a rotted grain incidence ranging from $3.06 \%$ to $3.36 \%$. The hybrid control used as resistance reference (CheckR) was the most resistant $(2.89 \%)$.

Table 2. Joint analysis by region. Incidences of rotted grain and corn grain yield data.

\begin{tabular}{cccccc}
\hline \multicolumn{3}{c}{ Cerrado } & \multicolumn{3}{c}{ Southern Brazil } \\
\hline Hybrids & $\begin{array}{c}\text { Rotten grain } \\
(\%)\end{array}$ & $\begin{array}{c}\text { Grain Yield } \\
\left(\mathrm{kg} \mathrm{ha}^{-1}\right)\end{array}$ & Hybrids & $\begin{array}{c}\text { Rotten grain } \\
(\%)\end{array}$ & $\begin{array}{c}\text { Grain Yield } \\
\left(\mathrm{kg} \mathrm{ha}^{-1}\right)\end{array}$ \\
\hline MH1 & 5.89 & 9.104 & MH1 & 9.03 & 10.858
\end{tabular}


Stenocarpella macrospora and Stenocarpella maydis...

\begin{tabular}{|c|c|c|c|c|c|}
\hline MH2* & 3.06 & 8.599 & MH2* & 4.06 & 11.693 \\
\hline MH3 & 4.40 & 7.598 & MH3 & 5.09 & 11.958 \\
\hline MH4 & 6.62 & 8.345 & MH4 & 6.51 & 10.885 \\
\hline MH5** & 6.35 & 8.701 & MH5 & 6.89 & 11.932 \\
\hline MH6 & 6.86 & 8.010 & MH6 & 6.41 & 9.009 \\
\hline MH7 & 7.31 & 7.521 & MH7 & 8.03 & 8.662 \\
\hline MH8 & 6.00 & 9.234 & MH8 & 4.86 & 11.665 \\
\hline MH9* & 3.17 & 9.222 & MH9 & 5.18 & 11.195 \\
\hline MH10 & 6.61 & 9.696 & MH10 & 7.64 & 11.320 \\
\hline MH11 & 5.57 & 8.456 & MH11 & 6.59 & 9.632 \\
\hline MH12 & 5.24 & 8.857 & MH12 & 6.12 & 10.740 \\
\hline MH13 & 5.67 & 7.943 & MH13 & 6.97 & 10.506 \\
\hline MH14 & 4.65 & 8.328 & MH14 & 5.76 & 10.487 \\
\hline MH15 & 7.41 & 8.524 & MH15 & 8.27 & 9.477 \\
\hline MH16 & 7.42 & 8.553 & MH16 & 8.11 & 10.947 \\
\hline MH17 & 7.30 & 8.777 & MH17 & 6.89 & 10.386 \\
\hline MH18 & 7.81 & 7.777 & MH18 & 7.46 & 11.312 \\
\hline MH19 & 7.59 & 8.678 & MH19 & 7.32 & 11.988 \\
\hline MH20 & 8.22 & 9.153 & MH20 & 6.06 & 10.424 \\
\hline MH21 & 7.79 & 7.735 & MH21 & 7.31 & 11.861 \\
\hline MH22 & 5.73 & 8.821 & MH22 & 5.81 & 10.903 \\
\hline MH23 & 9.22 & 7.533 & MH23 & 6.21 & 10.494 \\
\hline MH24 & 6.67 & 9.105 & MH24 & 6.58 & 11.321 \\
\hline MH25 & 5.48 & 8.766 & MH25 & 8.17 & 9.942 \\
\hline MH26 & 6.95 & 7.694 & MH26 & 6.17 & 12.040 \\
\hline MH27 & 6.60 & 7.978 & MH27 & 5.49 & 10.610 \\
\hline MH28 & 3.88 & 8.724 & MH28 & 5.35 & 10.678 \\
\hline MH29 & 6.10 & 9.023 & MH29 & 5.44 & 10.703 \\
\hline MH30 & 5.07 & 9.929 & MH30 & 5.04 & 11.253 \\
\hline MH31 & 5.00 & 7.905 & MH31 & 7.43 & 11.789 \\
\hline MH32 & 5.55 & 9.151 & MH32 & 5.79 & 12.336 \\
\hline MH33 & 5.84 & 9.045 & MH33 & 7.29 & 11.463 \\
\hline MH34 & 8.75 & 8.845 & MH34 & 5.78 & 11.504 \\
\hline MH35** & 6.25 & 8.149 & MH35 & 5.45 & 11.092 \\
\hline MH36 & 4.42 & 7.810 & MH36 & 6.12 & 9.689 \\
\hline MH37 & 5.12 & 7.280 & MH37 & 7.98 & 10.710 \\
\hline MH38 & 7.41 & 8.879 & MH38*** & 10.85 & 10.940 \\
\hline MH39 & 5.35 & 8.820 & MH39** & 6.69 & 11.905 \\
\hline MH40 & 5.47 & 8.263 & MH40 & 5.97 & 10.533 \\
\hline MH41* & 3.36 & 8.844 & MH41* & 4.56 & 10.493 \\
\hline MH42 & 4.61 & 8.757 & MH42 & 5.83 & 10.934 \\
\hline MH43 & 7.06 & 9.229 & MH43 & 8.96 & 10.668 \\
\hline MH44 & 4.18 & 7.890 & MH44 & 5.35 & 11.643 \\
\hline MH45 & 6.20 & 7.154 & MH45 & 5.95 & 9.482 \\
\hline MH46 & 3.97 & 7.412 & MH46 & 4.85 & 11.662 \\
\hline
\end{tabular}


MÁRIO, J. L.; GOZUEN, C. F.; JULIATTI, F. C.

\begin{tabular}{|c|c|c|c|c|c|}
\hline MH47 & 6.66 & 8.105 & MH47 & 7.10 & 10.640 \\
\hline $\mathrm{MH} 48 * * *$ & 9.58 & 8.225 & MH48 & 7.20 & 10.845 \\
\hline MH49 & 5.31 & 8.182 & MH49 & 6.03 & 10.190 \\
\hline MH50 & 3.82 & 8.539 & MH50 & 5.58 & 11.054 \\
\hline MH51 & 3.87 & 8.362 & MH51 & 6.59 & 11.353 \\
\hline MH52 & 6.21 & 8.054 & MH52* & 4.60 & 11.368 \\
\hline MH53 & 5.07 & 8.478 & MH53 & 7.86 & 10.476 \\
\hline MH54 & 7.52 & 7.526 & MH54 & 6.11 & 9.435 \\
\hline MH55*** & 9.52 & 7.213 & MH55 & 5.28 & 10.781 \\
\hline MH56 & 6.74 & 9.098 & MH56 & 8.42 & 11.707 \\
\hline MH57 & 6.54 & 7.733 & MH57 & 5.71 & 9.763 \\
\hline MH58 & 4.00 & 9.250 & MH58 & 5.82 & 11.308 \\
\hline MH59 & 7.62 & 7.738 & MH59 & 7.34 & 10.358 \\
\hline MH60 & 7.77 & 8.531 & MH60 & 7.52 & 9.467 \\
\hline MH61 & 5.07 & 7.853 & MH61 & 4.79 & 11.276 \\
\hline MH62 & 4.62 & 8.545 & MH62 & 6.50 & 11.094 \\
\hline MH63 & 4.74 & 7.116 & MH63 & 9.42 & 10.794 \\
\hline MH64 & 5.45 & 8.655 & MH64 & 5.06 & 11.115 \\
\hline MH65 & 5.23 & 7.104 & MH65 & 6.11 & 10.795 \\
\hline MH66 & 7.83 & 6.992 & MH66 & 7.44 & 11.447 \\
\hline MH67 & 8.66 & 8.316 & MH67 & 7.78 & 9.148 \\
\hline MH68 & 6.10 & 7.646 & MH68 & 5.97 & 9.967 \\
\hline MH69 & 7.96 & 5.239 & MH69 & 8.45 & 10.104 \\
\hline MH70** & 6.26 & 8.327 & MH70 & 7.68 & 11.021 \\
\hline MH71 & 6.13 & 7.709 & MH71 & 4.91 & 10.497 \\
\hline MH72 & 3.88 & 8.451 & MH72 & 4.85 & 10.116 \\
\hline MH73 & 4.66 & 6.767 & MH73 & 5.17 & 9.845 \\
\hline MH74 & 7.76 & 7.856 & MH74 & 8.43 & 11.217 \\
\hline MH75 & 6.14 & 7.458 & MH75 & 7.40 & 9.461 \\
\hline MH76 & 6.23 & 9.686 & MH76 & 5.62 & 11.646 \\
\hline MH77*** & 12.71 & 7.896 & MH77 & 8.11 & 8.916 \\
\hline MH78 & 7.36 & 6.840 & MH78 & 5.71 & 9.558 \\
\hline MH79 & 5.53 & 7.510 & MH79 & 5.49 & 11.173 \\
\hline MH80 & 7.95 & 7.431 & MH80 & 8.77 & 10.087 \\
\hline MH81 & 8.00 & 8.727 & MH81 & 6.38 & 10.911 \\
\hline MH82 & 3.54 & 8.375 & MH82 & 4.99 & 11.452 \\
\hline MH83** & 6.27 & 7.638 & MH83 & 8.11 & 10.306 \\
\hline MH84 & 8.67 & 9.488 & MH84** & 6.64 & 10.818 \\
\hline MH85 & 5.67 & 8.589 & MH85 & 7.66 & 11.311 \\
\hline MH86 & 6.75 & 7.721 & MH86 & 8.87 & 11.587 \\
\hline MH87 & 7.06 & 10.002 & MH87** & 6.79 & 11.336 \\
\hline MH88 & 6.36 & 9.428 & MH88 & 5.94 & 11.827 \\
\hline MH89*** & 11.50 & 5.550 & MH89*** & 14.25 & 8.055 \\
\hline MH90 & 5.57 & 7.763 & MH90 & 5.64 & 10.518 \\
\hline MH91 & 6.07 & 8.982 & MH91 & 8.40 & 11.784 \\
\hline
\end{tabular}


MÁRIO, J. L.; GOZUEN, C. F.; JULIATTI, F. C.

\begin{tabular}{|c|c|c|c|c|c|}
\hline MH92 & 5.79 & 8.206 & MH92 & 5.07 & 11.467 \\
\hline MH93 & 5.66 & 8.981 & MH93 & 6.96 & 11.177 \\
\hline MH94 & 4.95 & 8.852 & MH94 & 8.48 & 11.785 \\
\hline MH95 & 5.71 & 8.373 & MH95*** & 11.42 & 11.313 \\
\hline MH96 & 8.31 & 9.005 & MH96*** & 10.16 & 10.128 \\
\hline MH97 & 7.33 & 8.358 & MH97 & 7.22 & 10.733 \\
\hline MH98 & 7.10 & 7.349 & MH98 & 5.29 & 11.214 \\
\hline MH99 & 6.45 & 9.155 & MH99 & 6.99 & 9.604 \\
\hline MH100 & 4.11 & 9.556 & MH100 & 6.51 & 11.309 \\
\hline MH101 & 5.46 & 8.759 & MH101 & 5.62 & 9.486 \\
\hline MH102 & 7.73 & 8.042 & MH102 & 7.21 & 9.501 \\
\hline MH103** & 6.27 & 7.133 & MH103 & 8.07 & 10.630 \\
\hline MH104 & 7.50 & 9.405 & MH104** & 6.71 & 12.205 \\
\hline MH105 & 4.60 & 9.221 & MH105 & 8.21 & 11.889 \\
\hline MH106* & 3.29 & 8.881 & MH106 & 7.15 & 11.045 \\
\hline MH107 & 4.52 & 7.243 & MH107 & 6.48 & 11.862 \\
\hline MH108 & 7.12 & 8.876 & MH108 & 5.35 & 11.767 \\
\hline MH109 & 4.61 & 8.075 & MH109 & 4.81 & 10.554 \\
\hline MH110 & 6.73 & 9.475 & MH110 & 5.73 & 10.344 \\
\hline MH111 & 5.24 & 7.988 & MH111** & 6.87 & 9.472 \\
\hline MH112 & 4.79 & 8.254 & MH112* & 4.57 & 10.722 \\
\hline MH113 & 6.21 & 8.358 & MH113 & 4.61 & 11.214 \\
\hline MH114 & 6.47 & 9.170 & MH114 & 6.04 & 10.973 \\
\hline MH115 & 4.61 & 9.764 & MH115 & 5.34 & 12.642 \\
\hline MH116 & 7.38 & 7.389 & MH116 & 6.87 & 10.090 \\
\hline MH117 & 8.36 & 7.534 & MH117 & 7.94 & 10.805 \\
\hline MH118 & 7.62 & 8.430 & MH118 & 8.23 & 11.022 \\
\hline MH119 & 9.35 & 9.576 & MH119 & 6.58 & 11.680 \\
\hline MH120 & 6.83 & 8.705 & MH120 & 9.33 & 10.640 \\
\hline MH121 & 5.72 & 8.655 & MH121 & 4.78 & 11.122 \\
\hline MH122 & 6.40 & 8.684 & MH122 & 5.88 & 10.394 \\
\hline MH123 & 5.76 & 7.516 & MH123 & 8.23 & 9.868 \\
\hline MH124 & 5.84 & 7.856 & MH124 & 5.26 & 11.689 \\
\hline MH125 & 5.72 & 8.228 & MH125*** & 10.74 & 9.945 \\
\hline MH126 & 8.31 & 8.121 & MH126 & 8.50 & 10.180 \\
\hline MH127 & 4.40 & 9.187 & MH127 & 6.51 & 10.399 \\
\hline MH128*** & 13.16 & 7.251 & MH128 & 8.24 & 9.889 \\
\hline MH129 & 7.08 & 8.509 & MH129 & 6.24 & 11.094 \\
\hline MH130 & 8.53 & 8.918 & MH130 & 7.43 & 11.378 \\
\hline MH131 & 7.24 & 8.282 & MH131 & 9.58 & 12.004 \\
\hline MH132 & 5.37 & 9.579 & MH132 & 6.09 & 11.084 \\
\hline MH133 & 5.52 & 9.157 & MH133* & 4.60 & 11.782 \\
\hline MH134* & 3.22 & 9.610 & MH134 & 5.91 & 10.926 \\
\hline MH135 & 6.00 & 7.644 & MH135 & 6.51 & 10.158 \\
\hline MH136 & 6.02 & 9.556 & MH136 & 6.01 & 11.858 \\
\hline
\end{tabular}




$\begin{array}{lccccc}\text { MH137 } & 8.49 & 7.303 & \text { MH137 } & 9.40 & 10.528 \\ \text { MH138 } & 5.31 & 7.464 & \text { MH138 } & 5.80 & 9.647 \\ \text { MH139 } & 11.61 & 1.869 & \text { MH139 } & 7.36 & 7.312 \\ \text { MH140 } & 6.04 & 7.941 & \text { MH140 } & 6.87 & 11.338 \\ \text { CheckR } & 2.89 & 10.044 & \text { CheckR } & 4.40 & 11.848 \\ \text { CheckS } & 7.34 & 9.229 & \text { CheckS } & 7.52 & 11.748\end{array}$

Corn hybrids selected in each region for analysis of the health of damaged kernels: * Five hybrids with high resistance; ** Five hybrids with moderate resistance; *** Five hybrids with low resistance. Hybrids studied: MH 1-140. CheckR: resistance control. CheckS: susceptiblity control. Experimental Hybrids from Monsanto Company, Uberlândia, MG.

In the Southern Brazil joint analysis (Table 2), the most susceptible hybrids were: MH96, MH125, MH38, MH95 and MH89. These hybrids presented incidences ranging from $10.16 \%$ to $14.25 \%$, a higher incidence than the CheckS (7.52\%). Hybrids with lower disease percentages were MH2, MH41, MH112, MH52 and MH133. The MH2 hybrid was the most resistant $(4.06 \%)$, better than the resistance control CheckR (4.40\%).

The MH2 and MH41 hybrids exhibited disease resistance in both regions of the experiment. On the other hand, MH89 was found to be susceptible in both regions (Figure 2). The results indicated stability of the characteristics for these hybrids regardless region or climate where they were tested.

The hybrids expressed better productive potential when grown in the southern region (Table
2). Cerrado region production ranged from 1,869 to $10,044 \mathrm{~kg} \mathrm{ha}^{-1}$ while in the South it ranged from 7,312 to $12,642 \mathrm{~kg} \mathrm{ha}^{-1}$.

The Figure 1 represents incidences of $S$. macrospora, $S$. maydis and other fungi in the selected hybrids from the analysis of each region. The fungus $S$. maydis had the lowest incidence in all treatments, ranging from 10 to $13 \%$. Regardless region and environment, a prevalence of $S$. macrospora compared to $S$. maydis, was found in the rotted grain samples. The fungus $S$. macrospora had higher incidences when hybrids were tested in the Cerrado, with a grain rot incidence of $60 \%$, compared to $58 \%$ of grain rot incidence in the South. On the other hand, the percentage of other fungi, that also cause ear rot, was higher in the South (69\%) than in the Cerrado (61\%).

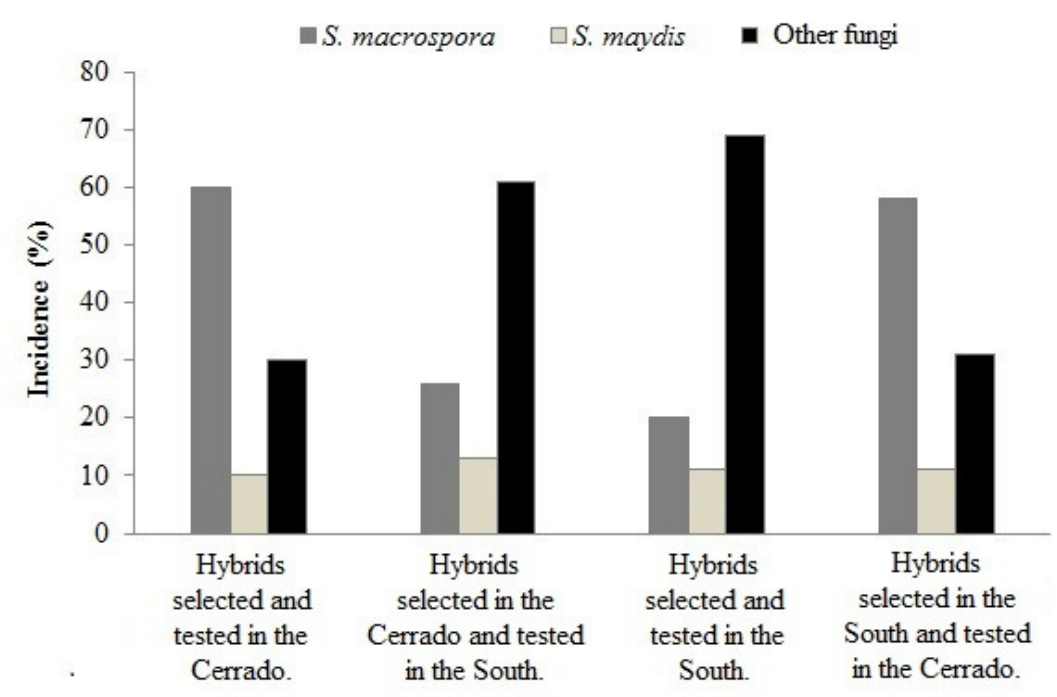

Figure 1. Incidence of rotted grain caused by S. macrospora, S. maydis and other fungi in hybrids selected in a joint analysis of the Cerrado and Southern Brazil regions. 
Between the three Cerrado localities (Figure 2), Iraí de Minas presented the highest incidence of S. macrospora $(72 \%)$ but also a lower S. maydis incidence (3\%). In Uberlândia $52 \%$ of the samples contained S. macrospora, 13\%, S. maydis and 35\% other fungi that cause rotting in grain; Araguari registered $43 \%, 23 \%$ and $34 \%$, respectively.

In the South the three locations studied included Abelardo Luz, Pinhão and Guarapuava.
MÁRIO, J. L.; GOZUEN, C. F.; JULIATTI, F. C.

Abelardo Luz exhibited a higher incidence of $S$. maydis (39\%) than S. macrospora ( 17\%) (Figure 3). Pinhão and Guarapuava had low S. maydis percentages, 1 and 2\%, respectively, compared to $S$. macrospora: 31 and 15\%, respectively. Thus, it was observed that Abelardo Luz was the only location where $S$. maydis presented a higher incidence than of $S$. macrospora (Figures 2 and 3 ).

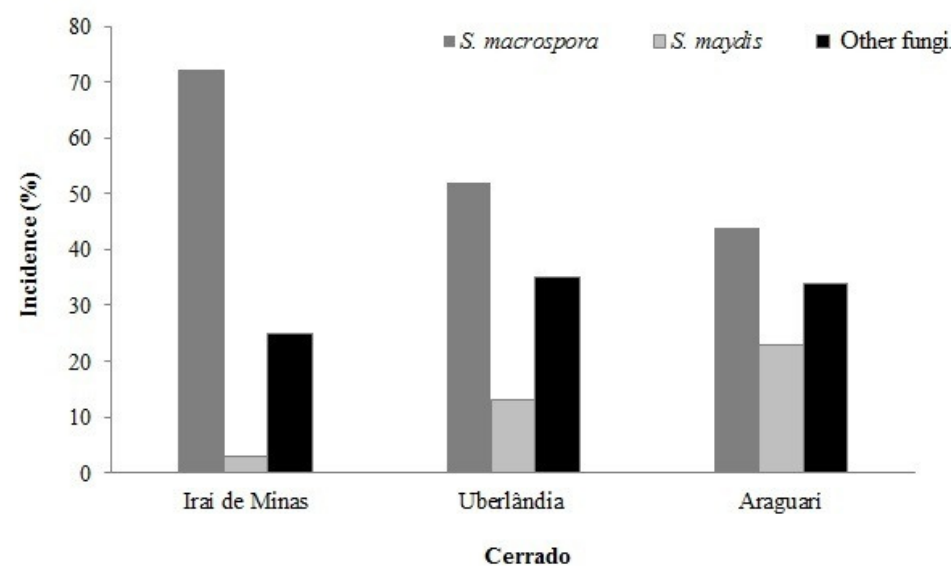

Figure 2. Incidence of rotted grain caused by S. macrospora, S. maydis and other fungi in hybrids selected from three localities in the Cerrado Region.

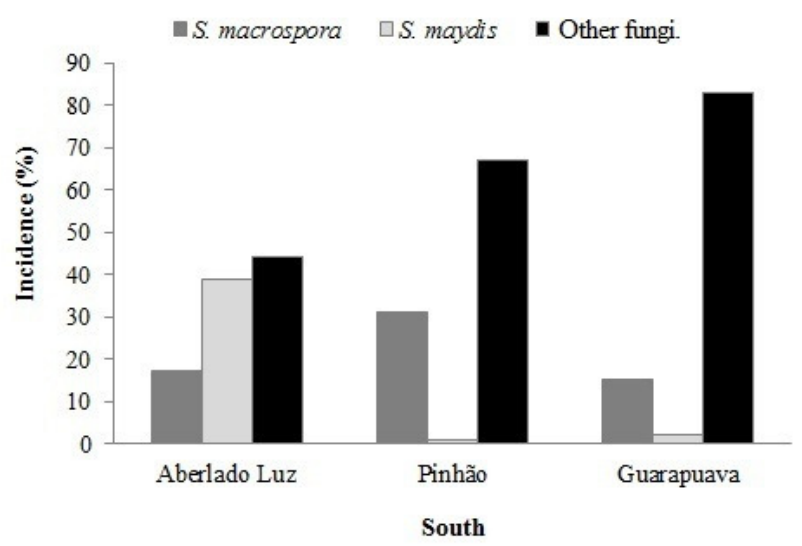

Figure 3. Incidence of rotted grain caused by S. macrospora, S. maydis and other fungi in hybrids selected from three localities of Southern Brazil region.

In summary, five resistant hybrids, five of medium strength and five susceptible hybrids were selected for running the joint analysis for each region (Table 2) and were used to verify incidences 
of S. macrospora, S. maydis and other fungi (Figures 1 to 3). The hybrid MH139, when analyzed in the Cerrado region, showed higher susceptibility than the hybrids MH55, MH48 and MH89 that had been selected for analysis but MH139 had low productivity (Table 2). Reasons for this result were not determined and will remain for subsequent analyzes.

The Stenocarpella spp. inoculation method utilized in this study permitted differentiation of resistant and susceptible corn genotypes. Studies have shown that natural inoculation efficiency is higher when compared to other methods such as the colonized-stick-tooth, that may cause difficulties in the assessment because of injuries caused when the colonized stick is introduced into the corn ear (BENSCH et al., 1992; MARIO et al., 2003; SILVA, et al., 2005).

In the South and Cerrado regions joint analysis, a significantly positive variance was obtained for the tested hybrids. The heritability coefficients were .46 and .43 in the Cerrado and the South, respectively (Table 1). A trend indicating higher disease expression in the Cerrado was thus suggested. Other studies have also verified genotype and environmental interaction, indicating the need to conduct grain rot resistance evaluations in different locations (DORRANCE et al., 1998; ROSSOUW et al., 2002a, 2002b).

The present study with 140 double-haploid corn hybrids demonstrated that it was possible to detect variations in rotted grain incidence (Table 2). Double haploid progenies presented high resistance to Stenocarpella spp. when compared to the resistant control (CheckR) and susceptible checking (CheckS). Differential responses from hybrids have been reported in terms of leaf spot and damage caused by Stenocarpella spp. Under ideal environmental conditions for disease hybrids classified as resistant may still have some degree of susceptibility (THOMPSON et al., 1971;. MARIO; PRESTES, 1997; TRENT et al., 2002; PASCUAL, et al., 2006). These results can be verified, for example, by the resistance control (CheckR), which had varying values between the Cerrado region $(2.89 \%)$ and the South $(4.40 \%)$ (Table 2).

The hybrids evaluated showed higher yields in the South (Table 2). However, the yield was not affected by grain quality. Similar studies have indicated that cob rot is also a factor that significantly reduces grain quality rather than grain yield. This is unlike cob rot diseases that can cause yield reduction (THOMPSON et al., 1971; TRENTO et al., 2002; MARIO et al., 2003).
MÁRIO, J. L.; GOZUEN, C. F.; JULIATTI, F. C.

Stenocarpella spp. grain rot incidence values showed a continuous distribution (data not presented), indicating the possibility that this resistance is conditioned by more than one factor. These results are consistent with previous studies reporting multiple genetic aspects as responsible for grain rot resistance when the rot is caused by Stenocarpella spp. (OLATINWO et al., 1999, GUTIERREZ, 2008).

Two hybrids in particular showed grain rot percentage values similar to the control results, in both regions: MH2 and MH41 (Table 2). This indicated that there may be genetic gains in grain rot selection incited by Stenocarpella spp. Certainly these will serve breeding programs as sources of Stenocarpella spp. resistance.

When incidences of $S$. macrospora, $S$. maydis and other fungi were tested and evaluated a higher incidence of $S$. macrospora, in relation to $S$. maydis (Figure 1) was observed in both regions.

These results are similar of those obtained by Mario et al., (2003), who found a fourfold incidence of $S$. macrospora $(12.36 \%)$ compared to $S$. maydis (3.25\%). This may be related to the fact that $S$. macrospora can infect corn leaves in addition to the grains and thus, the leaf spot conidia may serve as an inoculum source to increase incidences of rotted grain. Leaves are positioned near the infection site, the corn ear peduncle (MARIO; PRESTES, 1997; MARIO; REIS, 2003). Other research has reported that increases and intensity of stalk and grain rot may be associated with inoculum density, especially in leaves lesions (DEL RIO, 1990; FLETT; MCLAREN, 1994; HOUSE, 2000). Moreover, a higher incidence of $S$. macrospora can be attributed to greater inoculum availability in crop residues, where spores may have been released and carried by the wind to infection sites (MARIO; REIS, 2003).

Although the summer climatic conditions of southern Brazil (warm days and balmy nights) favor S. maydis development (PEREIRA, 1995), only in Abelardo Luz was the S. maydis incidence (39\%) higher than the incidence of $S$. macrospora (17\%) (Figure 3). According to Reis and Mario, 2003, most research in Brazil refers to S. maydis as one of the most frequent pathogens in corn, but this research have found similar incidences for both species. According to these authors, diagnoses based on mycelium coloring can generate equivocal results and incorrect diagnosis between the two pathogens. However, when using the method described by Mario and Reis (2001), pathogen identification is possible with a greater certainty, in order to recognize the differences between these two 
Stenocarpella species. Furthermore, it should be noted that in similar climatic situations, Brazil and South Africa for example, one of the main fungi associated with rotted grain in corn crop is Stenocarpella macrospora (MARASAS; VAN DER WESTHUIZEN, 1979).

\section{CONCLUSIONS}

There was a significant difference in the mean incidence of rotted grain between the Cerrado (savana conditions) and southern Brazil regions.
This suggested that there are genetic gains for this variable in hybrid selection and breeding programs.

The results identified environment effects on the prevalence of fungi that cause rotting in corn. There was a prevalence of S. macrospora in the Cerrado and other fungi non-Stenocarpella ssp. in southern Brazil.

Abelardo Luz was the only location where there was a higher incidence of $S$. maydis than of $S$. macrospora.

\section{ACKNOWLEDGMENTS}

To FAPEMIG for financial support.

RESUMO: Stenocarpella macrospora e Stenocarpella maydis em milho, podem resultar na morte de plântulas ou causar apodrecimento na base do caule e da totalidade ou parte da espiga. Além disso, S. macrospora pode causar manchas foliares. Identificou-se linhagens duplo-haplóides de híbridos de milho resistentes a S. macrospora e S. maydis; determinou-se também a incidência desses patógenos no Cerrado e do Sul do Brasil. Cento e quarenta híbridos duplohaplóides de milho além dos controles (testemunhas) foram inoculados com S. macrospora e S. maydis e avaliados quanto à resistência em três localidades do Cerrado e três de Sul do Brasil. Os grãos atacados pelos fungos foram colhidos e avaliados quanto à incidência dos dois patógenos. Foram estimadas as porcentagens (\%) de S. Macrospora e de S. Maydis e também a ocorrência de outros fungos pelo método de blotter. Houve maior presença de $S$. macrospora do Cerrado. No Sul do Brasil, o município de Abelardo Luz foi o único local onde S. maydis foi encontrado em maior incidência do que $S$. macrospora. Os resultados mostraram efeitos ambientais sobre a prevalência de fungos que causam grãos ardidos. Estes resultados indicaram ganhos genéticos na seleção de híbridos resistentes ao fungo S. Macrospora e obtenção de híbridos resistentes em milho, tanto na região do Cerrado como no Sul do Brasil.

PALAVRAS-CHAVE: Diplodia sp. Grãos ardidos. Duplo-haplóides

\section{REFERÊNCIAS}

BEESCH, M. J.; VAN STADEN, J.;RIKENBERG, J. H. Time and site of inoculation of maize for optimum infection of ears by Stenocarpella maydis. Journal of Phytopathology v. 136, p. 265-269, 1992.

https://doi.org/10.1111/j.1439-0434.1992.tb01308.x

CASA, R.T. Sobrevivência de Stenocarpella maydis e $S$. macrospora em restos culturais de milho. Tese de doutorado, Universidade Federal de Viçosa. Viçosa, MG, BR, 2000. https://doi.org/10.1590/S010041582006000500001

CASA, R. T.; REIS, E.M.; ZAMBOLIM, L. Doenças do milho causadas por fungos do gênero Stenocarpella. Fitopatologia Brasileira, Brasília, v. 31, p. 427-439, 2006.

DEL RIO, L. Maiz muerto en Honduras provocado por el complejo Diplodia y Fusarium. Manejo Integrado de Plagas, v. 18, p. 42-53, 1990.

DEIMLING, S.; ROBER, F.; GEIGER, H. H. Methodik und genetic der in-vivo haploideninduktion bei mais. Vortr Pflanzenzuchtung, v. 38, p. 203-204, 1997.

DORRANCE, A. E.; HINKELMAN, K. H.; WARREN, H. L. Diallel analysis of Diploida ear rot resistance in maize. Plant Disease, Saint Paul, v. 82, p. 699-703, 1998. https://doi.org/10.1094/PDIS.1998.82.6.699

EDDINS, A. H. Dry rot of corn caused by Diplodia macrospora Earle. Phytopathology, Saint Paul, v. 20, p. 439-448, 1930. 
FLETT, B. C.; MCLAREN, N. W. Optimum disease potential for evaluating resistance to Stenocarpella maydis ear rot corn hybridis. Plant Disease, Saint Paul, v. 78, p. 587-589, 1994. https://doi.org/10.1094/PD-780587

GUTIEREZ, H. Mapeamento de QTL's para resistência a grãos ardidos causados por Diplodia (Stenocarpella SP.) em milho (Zea mays L.). Dissertação de mestrado, Universidade Federal de Uberlândia. Uberlândia, MG, BR, 2008.

MARASAS, W. F. O.; VAN DER WESTHUIZEN, G. C. A. Diplodia macrospora: the cause of leaf blight and cob rot of maize (Zea mays) in South Africa. Phytophylactica, v. 11, p. 61-64, 1979.

MARIO, J. L.; PRESTES, A. M. Avaliação da resistência à mancha foliar causada por Diplodia, macrospora em genótipos de milho. Fitopatologia Brasileira, Brasília, v. 22, p. 280, 1997.

MARIO, J. L. Comparação de métodos de inoculação de Diplodia maydis em espigas de milho e reação de híbridos em condições de infecção natural de $D$. macrospora. Dissertação de mestrado, Universidade de Passo Fundo. Passo Fundo, RS, BR, 1998.

MARIO, J. L.; REIS, E. M. Método simples para diferenciar Diplodia macrospora de D. maydis em testes de patologia de sementes de milho. Fitopatologia Brasileira, Brasília, v. 26, n. 3, p. 670-672, 2001. https://doi.org/10.1590/S0100-41582001000300018

MARIO, J. L.; REIS, E. M. Quantificação do inóculo de Diplodia macrospora e de D. maydis em restos culturais, no ar e sua relação com a infecção em grãos de milho. Fitopatologia Brasileira, Brasília, v. 28, n. 2, p. 143-147, 2003. https://doi.org/10.1590/S0100-41582003000200004

MARIO, J. L.; REIS, E. M.; BONATO, E.M. Reação de híbridos de milho à podridão branca da espiga. Fitopatologia Brasileira, Brasília, v. 28, p. 155-158, 2003. https://doi.org/10.1590/S010041582003000200006

MARIO, J. L.; REIS, E. M.; JULIATTI, F. C. Three inoculation methods for screening corn germplasm to white ear rot resistance. Tropical Plant Pathology, Brasília, v. 36, n. 6, p. 362-366, 2011.

OLATINWO, R.; CARDWELL, K.; MENKIR, A.; DEADMAN, M.; JULIAN, A. Inheritance of resistance to Stenocarpella macrospora (Earle) ear rot of maize in the mid-altitude zone of Nigeria. European Journal of Plant Pathology, v. 105, p. 535-543, 1999. https://doi.org/10.1023/A:1008734815796

PASCUAL, C. B.; GUZMAN, P. S.; SALAZAR, A. M. Reaction of maize germplasm to Stenocarpella macrospora (Earle) infection and effect of resistance to disease development, International Plant Breeding Symposium. Book of abstracts. p. 50, 2006.

PEREIRA, O. A. P. Situação atual de doenças da cultura do milho no Brasil e estratégias de controle. In: Resistência Genética de Plantas a Doenças. Piracicaba. Departamento de Genética, Universidade de São Paulo. pp. 25-30, 1995.

PROZESKY, L.; KELLERMAN, T. S.; SWART, D. P. Perinatal mortality in lambs of ewes exposed to cultures of Diplodia maydis (= Stenocarpella maydis) during gestation. A study of the central-nervous-system lesions. Journal of Veterinary Research, v. 61, p. 247-253, 1994.

ROSSOUW , J. D.; VAN RENSBURG,, J. B. J.; VAN DEVENTER, C. S. Breeding for resistance to ear rot of maize, caused by Stenocarpella maydis (Berk) Sutton. 1. Evaluation of selection criteria. South African

Journal of Plant and Soil, Pretoria, v. 19, n. 4, p. 182-187, 2002a.

https://doi.org/10.1080/02571862.2002.10634462

https://doi.org/10.1080/02571862.2002.10634463 
ROSSOUW, J. D.; VAN RENSBURG, J. B. J.; VAN DEVENTER, C. S. Breeding for resistance to ear rot of maize, caused by Stenocarpella maydis (Berk) Sutton. 2. Inheritance of Resistance. South African Journal of Plant and Soil, Pretoria, v. 19, n. 4, p. 188-194, 2002, b. https://doi.org/10.1080/02571862.2002.10634462 https://doi.org/10.1080/02571862.2002.10634463

SILVA, A. D.; JULIATTI, F. C.; BRITO, C. H.; GOMES, L. S. Métodos de inoculação de Stenocarpella maydis, em três populações de milho. Summa Phytopatologica, v. 31, p. 182-86, 2005.

THOMPSON D.; VILLENA, W. L.; MAXWELL, J. D. Correlation between Diplodia stalk and ear rot of corn. Plant Disease Reporter, v. 55, p. 158-162, 1971.

TRENTO, S. M.; IRGANG, H.; REIS, E. M. Efeito de rotação de culturas, de monocultura e de densidade de plantas na incidência de grãos ardidos em milho. Fitopatologia Brasileira, Brasília, v. 27, p. 609-613, 2002. WOLOLOSHUK, C.; WISE, K. Diplodia Ear Rot. Purdue University, West Lafayette, 2008. 